\title{
ANALISIS KEPUTUSAN PEMBELIAN IPHONE APPLE YANG DILAKUKAN OLEH ORANG YANG TINGGAL DI JABODETABEK
}

\author{
Oleh: \\ Nouval Ahmad \\ Patricia Gabriella D. A \\ Syarifah Zalicha \\ BINUS University Alam Sutera, Tangerang, Indonesia \\ Email : Zalicha122@gmail.com
}

\section{Article Info \\ Article History : \\ Received 30 August - 2021 \\ Accepted 16 Sept - 2021 \\ Available Online 25 Sept - 2021}

Keyword :

Brand Image, Brand

Loyalty, Perceived Value,

Purchase Decision

\begin{abstract}
This research is motivated by the rapid development of smartphones, where smartphones are one of the main needs of human activity. Apple is a company that competes with one of its products, the iPhone. This study aims to determine whether the factors of Brand Image, Brand Loyalty and Perceived Value can determine iPhone purchasing decisions by consumers who live in Greater Jakarta. This research method uses quantitative research with descriptive analysis. The population and sample used the Indonesian people, especially the JABODETABEK area as the population subject to be studied. The number of samples used in this study were 372 people in Greater Jakarta using Apple iPhone to represent the entire population. This number is obtained from the calculation of the multivariate sample size where the number of variables is $x$ 10. The sampling method used in this study is a quantitative method in the form of a survey/questionnaire for data collection. The sampling technique used in this study uses nonprobability using Convenience Sampling. The results of this study indicate that Brand Image has no significant and positive effect on purchasing decisions made by consumers in Jabodetabek. While other variables, namely Brand Loyalty and Perceived Value have a significant and positive effect on purchasing decisions made by consumers in Greater Jakarta. Simultaneously, all independent variables, namely Brand Image, Brand Loyalty \& Perceived Value, relate to Apple iPhone Purchase Decisions in Greater Jakarta.
\end{abstract}

\section{PENDAhUluan}

Kemajuan teknologi yang pesat merupakan hal yang tidak dapat dihindarkan dari waktu ke waktu dan inovasi-inovasi yang diciptakan untuk memberikan manfaat dan efektifitas yang positif bagi kehidupan manusia. Teknologi juga memberikan banyak kemudahan, sekaligus cara baru dalam melakukan aktivitas manusia. Manusia juga telah menikmati banyak manfaat dari inovasi teknologi yang telah dihasilkan dalam satu dekade terakhir. Menurut (Dwiningrum \& Astuti, 2011), kemajuan teknologi saat ini benar-benar telah diakui dan dirasakan memberikan banyak kemudahan dan kenyamanan bagi kehidupan umat manusia.

Bisnis dalam bidang gadget smartphone sedang naik daun dalam beberapa tahun ini. Bisnis yang menjanjikan dengan pengguna smartphone bertambah tiap tahunnya dan terhitung pada kuartal 3 tahun 2013 menurut marketingland com mencapai 476.637.876 pengguna dan masih akan terus bertambah. 
Ketergantungan dalam pencarian informasi melalui internet, kemudahan dalam berkomunikasi, gadget sebagai jembatan tentu dianggap sebagai kebutuhan dalam era ini. Dalam peluang munculnya bisnis dalam bidang smartphone, produsen dituntut untuk dapat menghasilkan produk yang unggul, yang mampu bersaing, dan yang paling penting dapat diterima oleh kosumen sehingga dapat memenangkan persaingan tersebut. Seiring dengan perkembangan jaman, kini keputusan konsumen dalam membeli juga tidak lagi hanya mengacu pada pertimbangan secara ekonomis semata, tetapi lebih berorientasi pada seberapa nilai suatu produk itu sebanding dengan kualitas produk (Akbar et al., 2013).

Menurut data yang bersumber dari KOMINFO (Kementerian Komunikasi dan Informatika), ada penelitian yang dilakukan oleh lembaga riset pemasaran digital bernama Emarketer yang menunjukkan bahwa pada tahun 2018 jumlah pengguna smartphone yang berada di Indonesia sebanyak lebih dari 100 juta orang. Menurut techinasia.com dengan jumlah yang begitu besar Indonesia merupakan negara dengan pengguna aktif smartphone terbesar keempat di dunia setelah China, India, dan Amerika.

Smartphone merupakan salah satu dari sekian banyak teknologi yang berkembang pesat dari tahun ke tahun. Dengan berbagai macam merk, keunggulan, dan harga. Menurut Derry (2014), smartphone adalah perangkat atau instrumen elektronik yang memiliki tujuan dan fungsi praktis untuk membantu pekerjaan manusia. Dari pernyataan tersebut, Perusahaan Produsen Ponsel dituntut untuk tidak hanya menciptakan produk tetapi juga memahami keinginan dan kebutuhan pelanggan. Ini adalah hal-hal yang penting bagi produsen untuk dapat bersaing dengan pesaing. Dengan memahami perilaku pelanggan, produsen dapat menciptakan produk yang sesuai dengan keinginan pelanggan.

Apple merupakan perusahaan yang fokus di bidang elektronik. iPhone merupakan salah satu produk smartphone yang dikeluarkan oleh brand Apple. Mampu berinovasi hingga saat ini menjadikan iPhone sebagai perusahaan yang mampu bersaing secara sehat di industrinya. Apple iPhone sendiri merupakan salah satu produk yang paling populer dan menjadi pilihan banyak orang. Citra baik ditunjukkan oleh Merek Apple dalam mempercayai pelanggan untuk terus menggunakan merek Apple sebagai bagian dari kehidupan sehari-hari.

Citra merek, harga, dan kualitas produk merupakan beberapa faktor yang mempengaruhi keputusan pembelian. Citra merek adalah apa yang dipikirkan dan dirasakan pelanggan ketika mendengar atau melihat sebuah nama merek (Setiadi, 2003). Segala sesuatu yang menyangkut suatu perusahaan mulai dari kualitas, harga, dan pelayanan kepada pelanggan yang diberikan merupakan faktor dari citra merek. Disamping itu harga juga menjadi faktor bagi pelanggan dalam mengambil keputusan pembelian, tinggi rendahnya harga menentukan apakah akan terjadi pembelian. Kualitas produk tertentu mulai dari kecepatan, kualitas kamera yang bagus hingga memori yang besar termasuk dalam atribut keputusan pembelian pelanggan.

JABODETABEK merupakan salah satu daerah yang sebagian besar merupakan pengguna iPhone. Dari kuisioner yang dilakukan kepada masyarakat Jabodetabek, mayoritas pengguna iPhone memutuskan untuk membeli produk tersebut karena faktor brand image yang diberikan kepada penggunanya selain fitur yang canggih. Faktor apa saja yang mempengaruhi keputusan pembelian yang dilakukan pelanggan dalam membeli Apple iPhone?, Apakah ada hubungan antara Citra Merek / Citra Merek dengan Keputusan Pembelian?, Apakah ada hubungan antara Loyalitas Merek /Loyalitas Merek dengan Keputusan Pembelian? Dan apakah ada hubungan antara nilai yang dirasakan dengan Keputusan Pembelian?.

Berdasarkan dari hasil penelitian (Amilia, 2017), citra merek merupakan asosiasi dari semua informasi yang tersedia mengenai produk, jasa dan perusahaan dari merek yang dimaksud (Ratri, 2007). Citra terhadap merek berhubungan berhubungan dengan sikap yang berupa keyakinan dan preferensi terhadap suatu merek. Konsumen yang memiliki citra yang positif terhadap suatu merek, akan lebih memungkinkan untuk melakukan pembelian. Harga adalah sejumlah uang yang harus dibayar konsumen untuk mendapatkan sebuah produk atau jasa.

Tujuan dari penelitian ini adalah untuk mengetahui bahwa ketiga variabel bebas tersebut memiliki pengaruh yang signifikan terhadap variabel bebas yang dapat mengarahkan seorang pelanggan pada 
keputusan pembelian. Untuk mengetahui hubungan antara ketiga variabel tersebut, penelitian ini akan menggunakan model penelitian kuantitatif.

\section{KAJIAN PUSTAKA DAN PEGEMBANGAN HIPOTESIS \\ Citra Merek}

Citra merek sangat penting bagi semua pelanggan dalam membeli suatu barang. Brand image adalah sesuatu yang muncul dari sebuah brand atau merek itu sendiri. Setiadi (2003) berpendapat bahwa "citra merek mengacu pada skema memori merek, yang berisi interpretasi pelanggan tentang atribut, kekuatan, kegunaan, situasi, pengguna, dan karakteristik pemasar dan/atau karakteristik pembuat produk. /merek." Citra merek adalah apa yang dipikirkan dan dirasakan pelanggan ketika mendengar atau melihat nama merek. Selain itu, Schiffman dan Kanuk (2007) juga berpendapat bahwa "citra merek adalah kumpulan asosiasi tentang merek yang tersimpan di benak atau ingatan pelanggan."

Menurut Schiffman dan Kanuk (2007), 5 indikator menentukan Brand Image, yaitu: kualitas, terpercaya atau diandalkan, kegunaan atau Manfaat, harga, citra merek itu sendiri

Menurut (Ratri, 2007) ada 3 indikator menentukan Brand Image, yaitu: atribut Produk, manfaat konsumen dan kepribadian merek.

\section{Loyalitas Merek}

Loyalitas merek merupakan konsep pemasaran yang dibutuhkan agar merek atau brand tersebut dapat terus bertahan. Hal ini dikarenakan pentingnya menjaga loyalitas pelanggan terhadap merek tersebut. Menurut Rangkuti (2009) loyalitas merek adalah ukuran loyalitas pelanggan terhadap suatu merek. Giddens (2002) berpendapat bahwa loyalitas merek adalah pilihan yang dibuat oleh pelanggan untuk membeli merek tertentu dibandingkan dengan merek lain dalam satu kategori produk.

Menurut Hameed dan Kanwal (2018), Nama Merek menentukan Loyalitas Merek. Kemudian menurut Nawaz dan Usman (2011), Kepuasan dan Pelayanan Konsumen dapat menentukan dan menciptakan Brand Loyalty.

\section{Nilai Keuntungan}

Seperti yang dinyatakan oleh Lai (2004) nilai yang dirasakan adalah penilaian pelanggan secara keseluruhan atas manfaat produk berdasarkan apa yang mereka terima dan apa yang mereka berikan. Nilai yang dirasakan terdiri dari 4 aspek utama menurut Sweeney dan Soutar (2010) Yang pertama adalah Nilai Emosional, yaitu suatu utilitas yang berasal dari perasaan atau emosi positif yang timbul dari mengkonsumsi suatu produk. Yang kedua adalah Nilai Sosial, yaitu utilitas yang diperoleh dari kemampuan produk untuk meningkatkan konsep sosial diri pelanggan. Kemudian yang ketiga adalah Quality/Performance Value, yaitu utilitas yang diperoleh dari persepsi kualitas dan kinerja yang diharapkan dari suatu produk. Dan yang terakhir adalah Price/Value of Money, yaitu utilitas yang diperoleh dari produk karena pengurangan biaya jangka pendek dan biaya jangka panjang.

Menurut Cronin et al. (2000), Product Price and Benefit menciptakan Perceived Value. Sedangkan menurut Rust dan Oliver (2004), Service Consumption Experience juga dapat menciptakan Perceived Value.

Keputusan Pembelian/ Keputusan Pembelian

Menurut Swastha (2007), keputusan pembelian adalah suatu pendekatan untuk memecahkan masalah dalam aktivitas manusia untuk membeli barang atau jasa dalam memenuhi keinginan dan kebutuhannya yang terdiri dari pengenalan kebutuhan dan keinginan, pencarian informasi, evaluasi alternatif pembelian, keputusan pembelian. dan perilaku setelah pembelian. Seperti yang dinyatakan oleh Lamb (2008) juga, keputusan pembelian pelanggan adalah langkah demi langkah yang digunakan pelanggan saat membeli barang dan jasa. Menurut Schiffman dan Kanuk (2009), keputusan pembelian adalah pilihan dari dua atau lebih alternatif pilihan keputusan pembelian. Kutipan tersebut dapat diartikan bahwa seseorang dapat memutuskan untuk membeli suatu barang atau jasa jika terdapat beberapa pilihan. Keputusan untuk membeli dapat ditentukan oleh bagaimana proses pengambilan keputusan itu sendiri.

Menurut (Ria, 2013), terdapat 4 indikator yang mempengaruhi Keputusan Pembelian. Pertama, ketika suatu produk dibutuhkan oleh seseorang. Kedua, adanya faktor lingkungan yang mempengaruhi keputusan seseorang untuk membeli produk. Kemudian yang ketiga, ketika produk tersebut lebih baik diantara produk lainnya. Dan yang terakhir adalah ketika pengalaman orang lain menggunakan produk yang kemudian mempengaruhi seseorang dalam membeli suatu produk.

\section{Hipotesis \& Kerangka}

Menurut Sangadji dan Sopiah (2013), citra 
merek adalah suatu asosiasi yang dapat bersifat positif atau negatif tergantung pada persepsi seseorang terhadap suatu merek. Ditambahkan oleh Wicaksono (2013) bahwa sangat penting untuk mengembangkan citra merek dalam keputusan pembelian. Disini yang menjadi pembahasan utama adalah brand image Apple iPhone apakah berpengaruh signifikan terhadap keputusan pembelian Apple iPhone di Jabodetabek.

H1 : Brand Image berpengaruh signifikan dan positif terhadap Keputusan Pembelian Apple iPhone di Jabodetabek.

Menurut Aaker (1997), Loyalitas Merek adalah ukuran dari hubungan pelanggan terhadap suatu merek. Tambahkan referensi penelitian dari Astuti dan Cahyadi (2007) yang menunjukkan hasil bahwa loyalitas merek berpengaruh positif signifikan terhadap keputusan pembelian sepeda motor Honda di Surabaya. Dari pemikiran ini, kami membuat hipotesis

$\mathrm{H} 2$ : Brand Loyalty berpengaruh signifikan dan positif terhadap Keputusan Pembelian Apple iPhone di Jabodetabek.

Dalam Penelitian Yee dan San (2012) menunjukkan bahwa Perceived Value yang dirasakan pelanggan memiliki hasil yang positif dengan pembelian, hasil tersebut juga menunjukkan bahwa Perceived Value merupakan salah satu faktor yang meningkatkan perhatian pelanggan setiap kali mereka ingin membeli. Diperkuat dengan hasil penelitian dari Suprapti (2010) yang berjudul Analisis Pengaruh Perceived Value, Terhadap Keputusan Pembelian Pelanggan menunjukkan hasil nilai yang dirasakan berhubungan secara signifikan dengan Keputusan Pembelian.

H3: Perceived Value berpengaruh signifikan dan positif terhadap Keputusan Pembelian Apple iPhone di Jabodetabek.

Dalam menentukan hipotesis 4, penulis belum mendapatkan jurnal yang dapat memperkuat dan menjelaskan bahwa variabel Brand Image, Brand Loyalty dan Perceived Value berpengaruh signifikan dan positif terhadap Keputusan Pembelian. Namun dalam hal ini penulis akan mengkaji apakah terdapat pengaruh yang positif dan signifikan antara ketiga variabel terikat dengan satu variabel bebas.

H4: Brand Image, Brand Loyalty dan Perceived Value berpengaruh signifikan dan positif terhadap Keputusan Pembelian Apple iPhone di
Jabodetabek

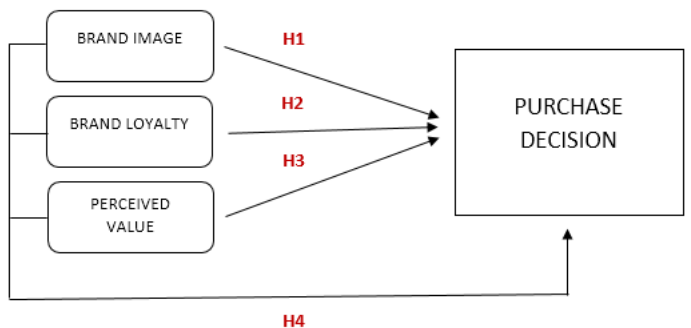

\section{METODE PENELITIAN}

Penelitian ini menggunakan jenis penelitian kuantitatif dengan analisis deskriptif. Populasi dan sampel menggunakan masyarakat Indonesia khususnya wilayah JABODETABEK sebagai subjek populasi yang akan diteliti. Jumlah sampel yang digunakan dalam penelitian ini adalah 372 orang di Jabodetabek yang menggunakan Apple iPhone untuk mewakili seluruh populasi. Jumlah ini diperoleh dari perhitungan ukuran sampel multivariat dimana jumlah variabel adalah $\mathrm{x}$ 10. Metode pengambilan sampel yang digunakan dalam penelitian ini adalah metode kuantitatif berupa survei/kuesioner untuk pengumpulan data.

Teknik sampling yang digunakan dalam penelitian menggunakan non-probability menggunakan Convenience Sampling. Survey ini khusus untuk pengguna Apple iPhone yang berdomisili di JABODETABEK.

Pengukuran Variabel

Semua variabel dalam penelitian ini diukur menggunakan skala Likert. Skala Likert digunakan untuk menguji seberapa kuat subjek setuju atau tidak setuju dengan pernyataan pada skala 5 poin dengan susunan sebagai berikut:

Sangat Setuju $(\mathrm{SA})=5$ poin

Setuju $(A)=4$ poin

Netral $(\mathrm{N})=3$ poin

Tidak Setuju (D) $=2$ poin

Sangat Tidak Setuju $(\mathrm{SD})=1$ poin

\section{HASIL DAN PEMBAHASAN Deskripsi Objek Penelitian}

Penelitian ini membahas secara singkat gambaran umum perusahaan, gambaran umum responden, dan analisis jawaban responden per variabel bebas dan terikat. Gambaran Umum Responden dalam penelitian ini adalah pengguna produk Apple iPhone di Jabodetabek. Hal ini sesuai dengan metode pengambilan sampel yang digunakan dalam penelitian ini yaitu nonprobability sampling yaitu teknik pengambilan sampel yang tidak memberikan kesempatan yang sama bagi setiap anggota populasi untuk 
dijadikan sampel. Berdasarkan data dari 698 responden yang menggunakan produk Apple iPhone di Jabodetabek, melalui daftar pertanyaan diperoleh kondisi responden tentang usia, domisili dan berbagai sudut pandang penggunaan iPhone. Klasifikasi yang dilakukan terhadap responden dalam penelitian ini bertujuan untuk mengetahui secara jelas gambaran responden sebagai objek penelitian.

\section{Uji Validitas}

Validitas berasal dari kata validitas yang berarti sejauh mana ketelitian suatu alat ukur dalam menjalankan fungsi ukurannya (Azwar 1986). Selain itu, validitas merupakan ukuran yang menunjukkan bahwa variabel yang diukur memang merupakan variabel yang hendak diteliti oleh peneliti (Cooper dan Schindler, dalam Zulganef, 2006). Sedangkan menurut Sugiharto dan Situnjak (2006) validitas berkaitan dengan suatu variabel yang mengukur apa yang seharusnya diukur. Validitas dalam penelitian menyatakan derajat ketelitian alat ukur penelitian terhadap isi sebenarnya yang diukur. Uji validitas adalah tes yang digunakan untuk menunjukkan sejauh mana alat ukur yang digunakan dalam mengukur apa yang diukur. Ghozali (2009) menyatakan bahwa uji validitas digunakan untuk mengukur validitas atau validitas suatu kuesioner.

Uji validitas digunakan untuk menguji setiap variabel yang digunakan dalam penelitian ini, dimana semua variabel dalam penelitian tersebut terdapat 31 item yang sudah dijawab oleh responden. Dalam uji validitas ini, penulis menggunakan analisis faktor hasil pemodelan dengan Confirmatory Factor Analysis (CFA) atau model penuh (full model) dengan structural equation modeling (SEM) akan bertemu dengan interpretasi loading factor. Menurut definisi, faktor pemuatan adalah korelasi besar antara indikator dan konstruk latennya. Dalam banyak ilmu sosial, pengukuran suatu konstruk sangat sering dilakukan secara tidak langsung melalui indikator-indikatornya. Indikator dengan loading factor tinggi memiliki kontribusi yang lebih tinggi untuk menjelaskan konstruk laten. Sebaliknya, indikator dengan loading factor yang rendah memiliki kontribusi yang lemah untuk menjelaskan konstruk laten. Di sebagian besar referensi. bobot faktor 0,50 atau lebih dianggap memiliki validasi yang cukup kuat untuk menjelaskan konstruk laten Hair et al (2010) \& Ghozali (2008). Padahal beberapa referensi lain seperti dari Sharma (1996) \&
Ferdinand (2000) menjelaskan bahwa loading factor terlemah yang dapat diterima adalah 0,40. Sehingga penulis memutuskan untuk mengikuti 0,40 sebagai angka terendah untuk loading factor dalam kasus ini. Berikut hasil uji validitas yang penulis lakukan dengan SPSS :

Hasil Uji Validitas

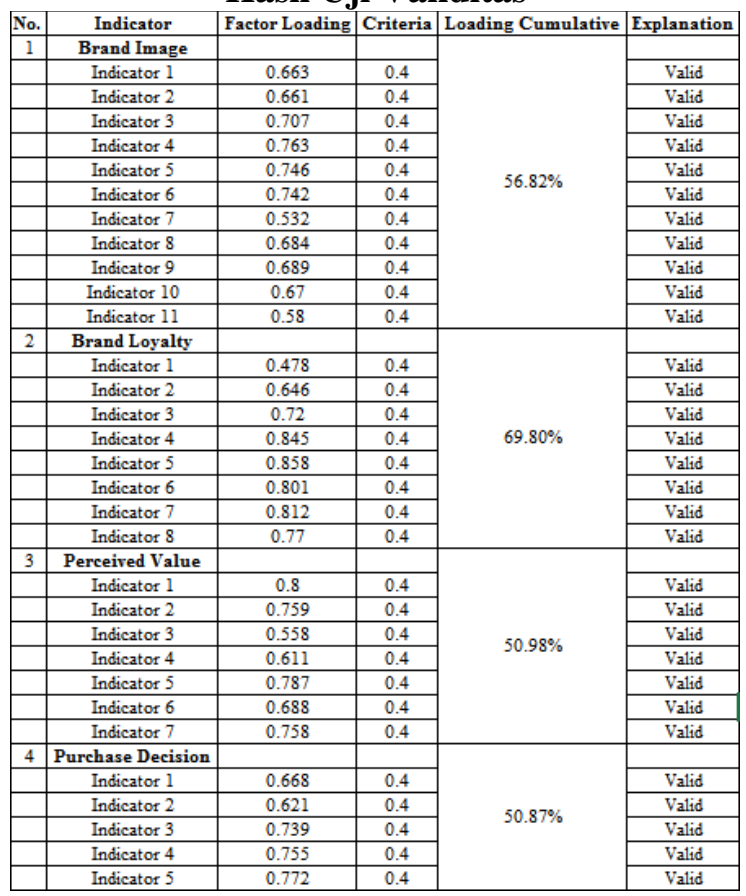

Hasil dari tabel di atas menunjukkan bahwa semua variabel memenuhi kriteria untuk dinyatakan valid, dengan hasil diatas 0,4. Sehingga dapat disimpulkan bahwa setiap variabel dalam penelitian ini adalah valid.

Seperti yang terlihat dari tabel Loading Cumulative, masing-masing variabel memiliki persentase yang berbeda-beda. Hasilnya menunjukkan seberapa kuat gratifikasi ini dapat menjelaskan variabel-variabel ini. Brand Image memiliki loading kumulatif sebesar 56,82\%. Hal ini menunjukkan bahwa masing-masing indikator dapat menjelaskan variabel Brand Image sebesar 56,82\%. Brand Loyalty memiliki pembebanan kumulatif sebesar $69,80 \%$. Hal ini menunjukkan bahwa masing-masing indikator dapat menjelaskan variabel Brand Loyalty sebesar 69,80\%. Perceived Value memiliki pembebanan kumulatif sebesar 50,98\%. Hal ini menunjukkan bahwa masing-masing indikator dapat menjelaskan variabel Perceived Value sebesar 50,98\%. Dan Keputusan Pembelian terakhir memiliki pembebanan kumulatif sebesar $50,87 \%$. Hal ini menunjukkan bahwa masingmasing indikator dapat menjelaskan variabel Keputusan Pembelian sebesar 50,87\%.

\section{Tes Kepercayaan}


Keandalan berasal dari kata reliabel. Arti reliabilitas adalah keteguhan pengukuran (Walizer, 1987). Sugiharto dan Situnjak (2006) menyatakan bahwa reliabilitas mengacu pada pemahaman bahwa instrumen yang digunakan dalam penelitian untuk memperoleh informasi yang digunakan dapat dipercaya sebagai alat pengumpulan data dan dapat mengungkapkan informasi yang sebenarnya di lapangan. Ghozali (2009) menyatakan bahwa reliabilitas adalah alat untuk mengukur kuesioner yang merupakan indikator variabel atau konstruk. Suatu kuesioner dikatakan reliabel jika jawaban seseorang terhadap suatu pernyataan konsisten atau stabil dari waktu ke waktu. Uji reliabilitas mengacu pada tingkat stabilitas, konsistensi, daya prediksi, dan akurasi. Pengukuran yang memiliki reliabilitas tinggi adalah pengukuran yang dapat menghasilkan data yang reliabel.

Tinggi rendahnya reliabilitas, secara empiris ditunjukkan dengan angka yang disebut nilai koefisien reliabilitas. Reliabilitas tinggi ditunjukkan dengan nilai Cronbach Alpha mendekati angka 1. Kesepakatan umum reliabilitas dianggap memuaskan jika 0,700. Reliabilitas instrumen diuji dengan menggunakan rumus Alpha Cronbach karena instrumen penelitian berupa angket dan skala bertingkat.

Berikut adalah hasil pengujian reliabilitas yang dilakukan pada variabel Citra Merek, Loyalitas Merek, Perceived Value dan Keputusan Pembelian.

Hasil Uji Reliabilitas

\begin{tabular}{|l|c|c|c|}
\hline \multicolumn{1}{|c|}{ Variable } & Cronbach's Alpha & Criteria & Explanation \\
\hline Brand Image & 0,762 & 0,7 & Reliable \\
\hline Brand Loyalty & 0,775 & 0,7 & Reliable \\
\hline Perceived Value & 0,774 & 0,7 & Reliable \\
\hline Purchase Decision & 0,777 & 0,7 & Reliable \\
\hline
\end{tabular}

Hasil dari tabel diatas menunjukkan bahwa variabel Brand Image, Brand Loyalty, Perceived Value dan Purchase Decision memiliki hasil Cronbach's Alpha diatas 0,7. Cronbach's Alpha merupakan ukuran reliabilitas yang memiliki nilai mulai dari nol sampai satu Hair et al., (2010). Menurut Eisingerich dan Rubera (2010), tingkat keandalan minimum Cronbach's Alpha adalah 0,70. Dengan demikian semua variabel kuesioner reliabel sehingga item-item pada masing-masing variabel tersebut layak untuk digunakan sebagai alat ukur.

\section{Uji Regresi Linier Berganda}

Analisis Regresi adalah model pengujian untuk mengetahui pola hubungan antara dua variabel atau lebih. Analisis regresi menggunakan konsep dasar korelasi tetapi memberikan lebih banyak informasi dengan menunjukkan hubungan linier antara dua variabel dalam bentuk persamaan. (Lind, Marchal \& Wathen, 2018) Untuk menjawab hipotesis dalam jurnal ini digunakan regresi linier berganda. Dimana penulis menguji apakah terdapat pengaruh yang signifikan dari variabel independen dalam hal ini yaitu Brand Image, Brand Loyalty dan Perceived Value terhadap variabel dependen yaitu Keputusan Pembelian. Kami melakukan uji regresi linier berganda sesuai dengan hipotesis kami. Variabel dapat dinyatakan berpengaruh jika $\mathrm{p}$-value $<0,05$. Ini adalah hasil dari Regresi Linier Berganda yang kami lakukan di SPSS-:

\begin{tabular}{|c|c|c|c|c|c|c|}
\hline \multicolumn{7}{|c|}{ Coefficients $^{a}$} \\
\hline \multirow[b]{2}{*}{ Model } & & \multicolumn{2}{|c|}{ Unstandardized Coefficients } & \multirow{2}{*}{$\begin{array}{c}\text { Standardized } \\
\text { Coefficients } \\
\text { Beta }\end{array}$} & \multirow[b]{2}{*}{$t$} & \multirow[b]{2}{*}{ Sig. } \\
\hline & & B & Std. Error & & & \\
\hline \multirow[t]{4}{*}{1} & (Constant) & 1.350 & .912 & & 1.481 & .139 \\
\hline & BI_Total & .038 & .035 & .066 & 1.103 & .271 \\
\hline & BL_Total & .182 & .044 & .277 & 4.097 & .000 \\
\hline & PV_Total & .364 & .047 & .475 & 7.731 & .000 \\
\hline
\end{tabular}

Dari hasil uji regresi linier berganda yang kami lakukan pada aplikasi SPSS, dapat disimpulkan bahwa

1. Brand Image tidak berpengaruh terhadap Keputusan Pembelian. Karena p-value 0,271 dan lebih dari 0,05 maka dapat dikatakan bahwa Brand Image tidak berpengaruh terhadap Keputusan Pembelian.

2. Loyalitas Merek berpengaruh terhadap Keputusan Pembelian. Karena p-value 0,00 dan ini lebih kecil dari 0,05 maka dapat dikatakan bahwa Citra Merek berpengaruh terhadap Keputusan Pembelian.

3. Perceived Value berpengaruh terhadap Keputusan Pembelian. Karena p-value 0,00 dan ini lebih kecil dari 0,05 maka dapat dikatakan bahwa Citra Merek berpengaruh terhadap Keputusan Pembelian.

\section{Uji-t Statistik (Sebagian)}

Uji-t digunakan untuk mengetahui seberapa jauh suatu variabel independen berpengaruh secara signifikan terhadap variabel dependen secara parsial maupun individual. Variabel dapat dinyatakan berpengaruh signifikan jika p-value < 0,05 dan variabel dinyatakan signifikan jika $\mathrm{T}$ Value $>1,65$. 


\begin{tabular}{|c|c|c|c|c|c|c|}
\hline \multicolumn{7}{|c|}{ Coefficients $^{a}$} \\
\hline \multirow[b]{2}{*}{ Model } & & \multicolumn{2}{|c|}{ Unstandardized Coefficients } & \multirow{2}{*}{$\begin{array}{c}\text { Standardized } \\
\text { Coefficients } \\
\text { Beta }\end{array}$} & \multirow[b]{2}{*}{$t$} & \multirow[b]{2}{*}{ Sig. } \\
\hline & & B & Std. Error & & & \\
\hline \multirow[t]{4}{*}{1} & (Constant) & 1.350 & .912 & & 1.481 & .139 \\
\hline & BI_Total & .038 & .035 & .066 & 1.103 & .271 \\
\hline & BL_Total & .182 & .044 & .277 & 4.097 & .000 \\
\hline & PV_Total & .364 & .047 & .475 & 7.731 & .000 \\
\hline
\end{tabular}

Berdasarkan hasil uji-t dapat dibuktikan sebagai berikut:

1. Hal ini menunjukkan bahwa nilai $\mathrm{T}$ Citra Merek adalah 1,103 dan hasil ini lebih rendah dari $\mathrm{T}$ tabel sebesar 1,65 dan hal ini membuktikan bahwa Citra Merek Apple iPhone tidak berpengaruh signifikan dan positif terhadap Keputusan Pembelian yang dilakukan oleh masyarakat Jabodetabek .

2. Pengaruh antara Loyalitas Merek terhadap Keputusan Pembelian memiliki nilai $\mathrm{T}$ hitung sebesar 4,097 dan hasil ini berada di atas $\mathrm{T}$ tabel sebesar 1,65 dan hal ini membuktikan bahwa Loyalitas Merek dari pelanggan Apple iPhone memiliki pengaruh yang signifikan dan positif terhadap Keputusan Pembelian oleh masyarakat Jabodetabek

3. Pengaruh antara Perceived Value terhadap Keputusan Pembelian memiliki nilai $\mathrm{T}$ sebesar 7,731 dan hasil ini berada di atas $\mathrm{T}$ tabel sebesar 1,65 dan hal ini membuktikan bahwa Perceived Value dari pelanggan Apple iPhone memiliki pengaruh yang signifikan dan positif terhadap Keputusan Pembelian oleh masyarakat Jabodetabek.

\section{Uji F Statistik (Serentak)}

Tujuan dilakukannya uji $\mathrm{F}$ adalah untuk mengetahui apakah variabel Independen yaitu Brand Image, Brand Loyalty, \& Perceived Value memiliki pengaruh yang sama terhadap variabel dependen yaitu Keputusan Pembelian. Pengukuran untuk ini adalah jika nilai $p$ di bawah 0,05 dan nilai $F$ lebih dari 2,65. Itu adalah jumlah tabel F.

\begin{tabular}{|c|c|c|c|c|c|c|}
\hline \multicolumn{7}{|c|}{ ANOVA $^{\mathrm{a}}$} \\
\hline \multicolumn{2}{|c|}{ Model } & $\begin{array}{l}\text { Sum of } \\
\text { Squares }\end{array}$ & df & Mean Square & $\mathrm{F}$ & Sig. \\
\hline \multirow[t]{3}{*}{1} & Regression & 2810.488 & 3 & 936.829 & 184.678 & $.000^{b}$ \\
\hline & Residual & 1856.637 & 366 & 5.073 & & \\
\hline & Total & 4667.124 & 369 & & & \\
\hline
\end{tabular}

Berdasarkan hasil. ANOVA menunjukkan nilai signifikansi 0,000 dan berada di bawah $\mathrm{p}$ value 0,05 . Dan hasil nilai $F$ hitungnya adalah 184.678. Nilai $F$ ini lebih besar dari $F$ Tabel yaitu 2,65. Dengan demikian dapat disimpulkan bahwa secara simultan (bersama-sama) masingmasing variabel Independen yaitu Brand Image, Brand Loyalty \& Perceived Value berhubungan dengan Keputusan Pembelian Apple iPhone di Jabodetabek. Artinya Brand Image, Brand Loyalty \& Perceived Value berpengaruh signifikan dan positif terhadap Keputusan Pembelian Apple iPhone di Jabodetabek.

Demikian pembahasan dari penelitian yang dilakukan untuk melihat Keputusan Pembelian Apple iPhone yang dilakukan oleh masyarakat yang berdomisili di Jabodetabek apakah dipengaruhi oleh Brand Image, Brand Loyalty \& Perceived Value, berikut pembahasannya :

H1 ditolak; karena hasil menunjukkan bahwa Citra Merek tidak berpengaruh positif dan signifikan terhadap Keputusan Pembelian, hal ini menunjukkan bahwa Citra Merek p-value di bawah 0,05 dan nilai $\mathrm{T}$ Citra Merek di bawah 1,65. Artinya, orang yang membeli iPhone Apple dan berdomisili di Jabodetabek Keputusan pembelian untuk membeli ponsel tersebut tidak dipengaruhi oleh Citra Merek.

H2 diterima; karena hasil menunjukkan bahwa Brand Loyalty telah memenuhi kriteria. Hal ini menunjukkan bahwa nilai p-value Loyalitas Merek > 0,05 dan nilai $\mathrm{T}$ Loyalitas Merek > 1,65 (T tabel). Dari hasil tersebut dapat diketahui bahwa konsumen Apple iPhone yang berdomisili di Jabodetabek memiliki tingkat loyalitas yang tinggi terhadap Apple iPhone sehingga mempengaruhi konsumen dalam keputusan pembelian Apple iPhone mereka.

H3 diterima; karena hasil tersebut menunjukkan bahwa Perceived Value telah memenuhi kriteria. Hal ini menunjukkan bahwa Perceived Value p-value $>0,05$ dan Perceived Value $\mathrm{T}$ value > 1,65 ( $\mathrm{T}$ tabel). Dari hasil tersebut, terlihat bahwa setiap konsumen Apple iPhone rela membayar dengan harga yang cukup tinggi asalkan mendapatkan setara dengan apa yang mereka bayarkan.

H4 diterima; karena hasil penelitian menunjukkan bahwa Brand Image, Brand Loyalty \& Perceived Value berpengaruh positif dan signifikan terhadap Keputusan Pembelian Apple iPhone di Jabodetabek. Nilai F > 2,65 (F tabel). Sehingga masyarakat di Jabodetabek memutuskan untuk membeli Apple iPhone karena jika ketiga variabel tersebut digabungkan maka memberikan pengaruh yang positif dan signifikan. Dan itulah salah satu alasan orang yang tinggal di Jabodetabek memutuskan untuk membeli iPhone Apple. 
Berdasarkan dari hasil penelitian di atas maka diperkuat oleh hasil penelitian Schiffman dan Kanuk (Adrian Junio Adiwidjaja \& Tarigan, 2017) konsumen cenderung untuk mempercayai produk dengan merek yang disukai ataupun terkenal. Alasan inilah yang mendasari perusahaan untuk memperkuat posisi merknya agar tercipta brand image (citra merek) yang positif dan menancap kuat dalam benak konsumen. Melalui brand image, konsumen mampu mengenali sebuah produk, mengevaluasi kualitas, mengurangi resiko pembelian, dan memperoleh pengalaman dan kepuasan dari diferensiasi produk tertentu.

Hal sesuai dengan penelitian Netemeyer (Gunawan, 2019) persepsi kualitas yang baik, nilai sebuah produk juga sangat di pentingkan di benak konsumen, Perceived value merupakan persepsi terhadap nilai barang yang di terima oleh konsumen (kepuasan, kualitas) dan harga yang di berikan untuk membeli sebuah barang relatif terhadap merek.

Hal ini sejalan dengan penelitian terdahulu yang diteliti oleh Massie (Putri \& Deniza, 2018) tentang ekuitas merek produk. Penelitian beliau menghasilkan bahwa brand awareness memiliki pengaruh signifikan terhadap keputusan pembelian. Nilai koefisien korelasi berganda (R2) sebesar 0,828 artinya terdapat hubungan yang kuat antara variabel bebas (Kesadaran Merek, Persepsi Kualitas, Asosiasi Merek, dan Loyalitas Merek) dengan variabel tergantungnya (Keputusan Pembelian).

\section{KESIMPULAN}

Brand Image Apple iPhone tidak berpengaruh terhadap Keputusan Pembelian. Kekuatan pengaruh Citra Merek Apple iPhone tidak berpengaruh signifikan terhadap Keputusan Pembelian yang dilakukan oleh masyarakat Jabodetabek. Loyalitas Merek Apple iPhone berpengaruh terhadap Keputusan Pembelian. Daya pengaruhnya signifikan terhadap Keputusan Pembelian oleh masyarakat Jabodetabek. Apple iPhone Perceived Value memiliki kekuatan yang berpengaruh terhadap Keputusan Pembelian. Pengaruhnya signifikan terhadap Keputusan Pembelian oleh masyarakat Jabodetabek. Secara simultan semua variabel independen yaitu Brand Image, Brand Loyalty \& Perceived Value berhubungan dengan Keputusan Pembelian Apple iPhone di Jabodetabek.

\section{REFERENSI}

Anton A Setyawan, Kussudiyarsana, Imronudin (2015). Brand trust and Brand loyalty, an Empirical Study in Indonesia consumers. Eajournals, 4(3), 37-47.

Adrian Junio Adiwidjaja, \& Tarigan, Z. J. H. (2017). Pengaruh Brand Image Dan Brand Trust Terhadap Keputusan Pembelian Sepatu Converse. Agora, 5(3).

Akbar, M. F. D., Lubis, N., \& Listyorin, S. (2013). Pengaruh Citra Merek Dan Kualitas Produk Terhadap Keputusan Pembelian Pada Pemilik Iphone(Studi Pada Mahasiswa S1 Fakultas Ilmu Sosial dan Ilmu Politik Universitas Diponegoro. Jurnal Ilmu Administrasi Bisnis, 4(24).

Amilia, S. (2017). Pengaruh Citra Merek, Harga, dan Kualitas Produk terhadap Keputusan Pembelian Handphone Merek Xiaomi di Kota Langsa. Jurnal Manajemen Dan Keuangan Unsam, 6(1), 660-669.

Aypar Uslu, Beril Durmus, Sina Tasdemir. (2013). Word of Mouth, Brand Loyalty, Acculturation and the Turkish Ethnic Minority Group in Germany. Social and Behavioral Sciences, 99. 455-464.

Blackwell, R.D., P.W. Miniard andJ.F Engel. (2006). Customer Behavior (10th Ed.) Southern Thomson, USA-: Southern Western Publisher.

Bob Foster. (2016). Impact of Brand Image on Purchasing Decision on Mineral Water Product "Amidis" (Case Study on Bintang Trading Company), American Research Journal of Humanities and Social Sciences, 2. 6-10

Choy Jhonn Yee \& Ng Cheng San. (2011). Customer's Perceived Quality, Perceived Value and Perceived Risk Towards Purchase Decision on Automobile. American Journal of Economics and Business Administration 3(1), 47-57.

Dr. Hsinkuang Chi, Dr. Huery Ren Yeh \& Yi Ching Tsai. (2011). The influences of Perceived Value on Customer Purchase Intention-: The Moderating Effect of Advertising Endorser. Jims Journal.

Dwi Ajeng Wulandari \& Farah Oktafani. (2017). Pengaruh Brand Image Terhadap Proses Keputusan Pembelian Sepatu NIKE. Jurnal Computech dan Bisnis, 11(1), 5051.

Dwiningrum, \& Astuti, S. I. (2011). Desentralisasi dan Partisipasi Masyarakat 
dalam Pendidikan. Pustaka Pelajar.

Ermawan Galih Prasetya, Edy Yulianto \& Sunarti. (2018). Pengaruh Brand Image Terhadap Keputusan Pembelian (Survei Pada Mahasiswa Fakultas Ilmu Administrasi Bisnis Program Studi Administrasi Bisnis Angkatan 2014 Konsumen Air Mineral Aqua). Jurnal Administrasi Bisnis (JAB), 62(2).

Faisal Munif Soim, Suharyono \& Yusri Abdillah. (2016). Pengaruh Brand Image Terhadap Keputusan Pembelian (Studi Pada Pembeli Kartu Perdana simPATI di Booth Telkomsel Matos). Jurnal Administrasi Bisnis (JAB), 35(1).

Fitria Engla Sagita. (2013). Pengaruh Brand Image dan Harga Terhadap Keputusan Pembelian Ulang Produk Kentucky Fried Chicken (KFC) di Cabang Basko Grand Mall Oleh Mahasiswa Universitas Negeri Padang. E Jurnal.

Gunawan, A. (2019). Pengaruh Perceived Quality , Perceived Value Dan Brand Personality Terhadap Brand Loyalty Dari Produk Fashion Cotton- on Di Surabaya. Jurnal Strategi Pemasaran, 1-10. http://publication.petra.ac.id/index.php/m anajemen-

pemasaran/article/view/8552/7726

Huda, Fatkhan. (2019). Pengertian Gadget. Diakses pada 21 Februari 2020, from http://fatkhan.web.id/pengertiangadget-smartphone/

Millward, Steven. (2014). Indonesia to be world's fourth-largest smartphone market by 2018. Diakses pada 21 Februari 2020, from https://www.techinasia.com

Muhammad Alfiyan Najib, Harry Soesanto, I Made Sukresna. (2016) Analisis Pengaruh Brand Awareness, dan Preceived Value terhadap Keputusan pembelian. E Jurnal, 15(1), 62-73.

Noor-UI-Ain Nawaz, Ahmad Usman. (2011). What Makes Customers Brand Loyal: A Study On Telecommunication Sector of Pakistan. ResearchGate Journal, 2(14).

Nugroho, S. (2003). Konsep dan Implikasi Untuk Strategi dan Penelitian Bisnis Pemasaran. Jakarta: Prenada Media.

Putri Anggreni. (2015). Pengaruh Perceived Value Terhadap Kepuasan dan Minat Beli Ulang Pelanggan Pasar Umum Ubud. Jurnal Telaah Bisnis, 16(2), 115.

Ratri. (2007). Hubungan Antara Citra Merek
(Brand Image) operator Seluler Dengan Loyalitas Merek (Brand Loyalty) Pada Mahasiswa Pengguna Telepon Seluler Di Fakultas Ekonomi Reguler Universitas Diponegoro Semarang. Universitas Diponegoro: Semarang.

Rahab, Sri Retno Handayani \& Alisa Tri Nawarini. (2015). Peran Perceived Value dan Kepuasan Pelanggan Dalam Upaya Membangun Loyalitas Pengguna Kartu Seluler. Jurnal Media Ekonomi dan Manajemen, 30(1), 81-82.

Ria, P. (2013). Pengaruh promosi penjualan (Sales Promotion) terhadap proses keputusan pembelian kepada telkom vision bandung. In Universitas Widyatama. Universitas Widyatama.

Rizwan Qaiser Danish, Muhammad Khalid Khan, Muhammad Muddasar Ghafoor, Ishfaq Ahmad, Asad Afzal Humayon, Saqib Aslam. (2018). Impact of Brand Loyalty in Assessing Purchase Intentions of a Customer: A Study of Automobile Industry in South Asian Perspective. ResearchGate Journal, 33(2), 347-364.

Saturninus Andreas Adi Hanjaya Hngau, Sri Mintarti \& Yohanes Kuleh (2012). Pengaruh Brand Loyalty dan Perceived Quality Terhadap Keputusan Pembelian Handphone Nokia. Jurnal Kinerja, 9(2).

Shahid Hameed, Munaza Kanwal. (2018), Effect of Brand Loyalty on Purchase Intention in the Cosmetics Industry. MacroThink Journal, 5(1).

Suri Amilia, M. Oloan Asmara Nst. (2017). Pengaruh Citra Merek, Harga, dan Kualitas Produk terhadap Keputusan Pembelian Handphone Merek Xiaomi di Kota Langsa. Jurnal Manajemen dan Keuangan, 6(1).

Tiara Purba. (2016), Analisis pengaruh Citra merek, Persepsi harga dan Kualitas produk terhadap keputusan pembelian Smartphone Blackberry. ( Esa Unggul, 2016) diakses dari https://digilib.esaunggul.ac.id/public/UE U-Undergraduate-8177-cover.pdf

Vishwas Maheshwari, George Lodorfos, Sirril Jacobsen. (2014). Determinants of Brand Loyalty: a Study of the ExperienceCommitment-Loyalty Constructs. Sciedu Journal, 5(6).

Yayuk Yuliana \& Mardi Giwa Putra. (2018). Pengaruh Perceived Quality dan Brand Loyalty Terhadap Keputusan Pembelian 
Pada Konsumen SIM Card. Jurnal Akrab Juara, 3(2). 10-14.

Yesi Apriyani. (2013). Pengaruh Brand Image,

Harga dan Kualitas Pelayanan Terhadap Keputusan Pembelian Ulang Pizza Hut di Kota Padang. Padang: Universitas Negeri Padang. 